\begin{tabular}{cc|c}
\hline Tar. Bil. Der. & Journal of Agricultural Sciences \\
& $\begin{array}{c}\text { Dergi web sayfası: } \\
\text { www.agri.ankara.edu.tr/dergi }\end{array}$ & Journal homepage: \\
& www.agri.ankara.edu.tr/journal
\end{tabular}

\title{
Determination of Cross-Pollination Ratio in Safflower (Carthamus tinctorius L.) Using Different Experimental Designs
}

\author{
Nilüfer KOÇAK ${ }^{\mathrm{a}}$, Mesut UYANIK ${ }^{\mathrm{a}}$, Bilal GÜRBÜZZ ${ }^{\mathrm{a}}$, Erman BEYZI' \\ aAnkara University, Faculty of Agriculture, Department of Field Crops, 16110, Dışkapı, Ankara, TURKEY \\ ${ }^{{ }^{b}}$ Erciyes University, Faculty of Seyrani Agriculture, Department of Field Crops, Develi, Kayseri, TURKEY
}

\section{ARTICLE INFO}

Research Article DOI: 10.1501/Tarimbil 0000001272

Corresponding Author: Nilüfer KOÇAK, E-mail: nkocak@ankara.edu.tr, Tel: +90 (312) 5961539

Received: 02 October 2013, Received in Revised Form: 18 November 2013, Accepted: 09 December 2013

\begin{abstract}
This study was carried out to determine cross-pollination ratio in safflower (Carthamus tinctorius L.) using various experimental designs during summer seasons of 2012-2013. Two safflower (Carthamus tinctorius L.) cultivars having two different characters (spiny and spineless) were used as the study material. The cultivars with spiny (Balci) was used as a donor and spineless cultivar (Yenice) was used as a receptor. The results demonstrated that average cross-pollination ratio ranged between $1.12 \%$ and $7.71 \%$. The highest cross-pollination ratio was obtained from third experimental design that receptor and donor plants were mixed in 10 rows with $50 \mathrm{~cm}$ row space, while the lowest ratio was in north direction of forth experimental design, which receptor plants were sown in south and north directions. Average cross- pollination ratio was $3.49 \%$ in Ankara conditions. There were differences among the experimental designs in respect to crosspollination. The results of this research showed that cross-pollination ratio decreased when distance between donor and receptor plants increased.
\end{abstract}

Keywords: Carthamus tinctorius; Cross-pollination ratio; Experimental design

\section{Farklı Deneme Desenleri Kullanılarak Aspir (Carthamus tinctorius L.)'de Yabancı Döllenme Oranının Belirlenmesi}

\section{ESER BILGISI}

Araştırma Makalesi

Sorumlu Yazar: Nilüfer KOÇAK, E-mail: nkocak@ankara.edu.tr, Tel: +90 (312) 5961539

Geliş Tarihi: 02 Ekim 2013, Düzeltmelerin Gelişi: 18 Kasım 2013, Kabul: 09 Aralık 2013

\section{ÖZET}

Bu çalışma 2012 ve 2013 yıllarında Ankara Üniversitesi, Ziraat Fakültesi, Tarla Bitkileri Bölümü deneme tarlasında yürütülmüştür. Dikenli ve dikensiz olmak üzere iki aspir (Carthamus tinctorius L.) çeşidi deneme materyali olarak kullanılmıştır. Dikenli Balcı çeşidi polen verici olarak, dikensiz Yenice çeşidi ise polen alıcı olarak denemede yer almıştır. Ortalama yabancı döllenme oranı \% 1.12 ile \% 7.71 arasında değişim göstermiştir. En yüksek yabancı döllenme 
oranı, bitkilerin $50 \mathrm{~cm}$ sıra arasıyla 10 sıra halinde karışık olarak ekildiği üçüncü deneme deseninden; en düşük yabanc1 döllenme oranı ise bitkilerin kuzey-güney yönünde ekildiği dördüncü deneme deseninin kuzey yönünden elde edilmiştir. Ankara koşullarında ortalama yabancı döllenme oranı \% 3.49 olarak gerçekleşmiştir. Deneme desenleri arasında yabancı döllenme oranı bakımından farklılıklar ortaya çıkmıştır. Bu araştırma, polen alıcı bitkilerin, polen verici bitkilerden uzaklaştığı ölçüde yabancı döllenme oranının azaldığını ortaya koymuştur.

Anahtar Kelimeler: Carthamus tinctorius; Yabancı dölenme oranı; Deneme deseni

(C) Ankara Üniversitesi Ziraat Fakültesi

\section{Introduction}

Safflower (Carthamus tinctorius L.), a member of the Asteraceae family, is grown in semi-arid regions preliminary in Asia, Mexico, Iran and North America (Knowles 1989; Golkar et al 2010). It is an important plant as economically, obtained oil and dye from its seed and flower (Yenice \& Bayraktar 1996). Also low production cost and lesser water and nutrient needs of safflower appeal to farmers as an alternative plant in fallow areas (Cosge \& Kaya 2008).

Safflower is a plant that hermaphrodite flower with high proportion of self-pollinated (Baydar \& Gökmen 2003). Foreign pollinated rate of safflower is between $5-40 \%$ (Classen 1950). Hybridization studies have been focused on the inheritance of genes controlling flower color and leaf spiny in safflower genotypes (Pahlavani et al 2004; Rudolphi et al 2008). The spiny is dominant on the spineless and the orange color flower is dominant on yellow flower color (Pahlavani et al 2004). There are very few studies concerning safflower cross-pollination and hybridization (Gurbuz \& Ekiz 1990; Velasco et al 2012; Nabloussi et al 2013). For this reason, this research was carried out to determine the cross-pollination ratio in safflower using different experimental designs and examine role of direction on cross-pollination.

\section{Material and Methods}

This research was carried out at the University of Ankara, Faculty of Agriculture and Field Crops Department in summer seasons of 2012 and 2013. Two cultivars whit spiny and yellow flower (Balci), and spineless with orange flower (Yenice), were used as the study materials. Spiny character was found to be dominant over the spineless (Golkar et al 2010). Cultivar Yenice was used as the pollen receptor and cultivar Balci was used as the pollen donor. Seeds were sown on 20 March 2012 in all experimental designs. The both cultivars flowered synchronously.

Four different experimental designs were used to determine the cross-pollination ratio in this study (Figure 1). In the first experimental design, there were four squares inside each other. The sides of the innermost square were $2 \mathrm{~m}$ long. There was $50 \mathrm{~cm}$ space between the other three squares. The seeds of pollen donor plants were sown in the innermost square and the seeds of the pollen receptor plants were sown in the other three squares.

In the second experimental design, there were 10 rows. Space between the rows was $50 \mathrm{~cm}$ and each row was $3 \mathrm{~m}$ long. Each row was divided into two equal parts. The seeds of receptor plants were sown in first part and the seeds of donor plants were sown in the second part. Pollen receptor and pollen donor rows were located diagonally.

In the third experimental design, there were 10 rows. Space between the rows was $50 \mathrm{~cm}$ and each row was $3 \mathrm{~m}$ long. The seeds of receptor and donor plants were mixed equally and then the mixed seeds were sown in 10 rows. Pollen receptor and pollen donor plants were grown together in the same row. Only spineless plants were harvested in each row.

In the fourth experimental design, the seed of pollen donor plants were sown in double rows spaced $50 \mathrm{~cm}$ apart. The seeds of receptor plants were sown in south and north directions of pollen 
1. E.D.

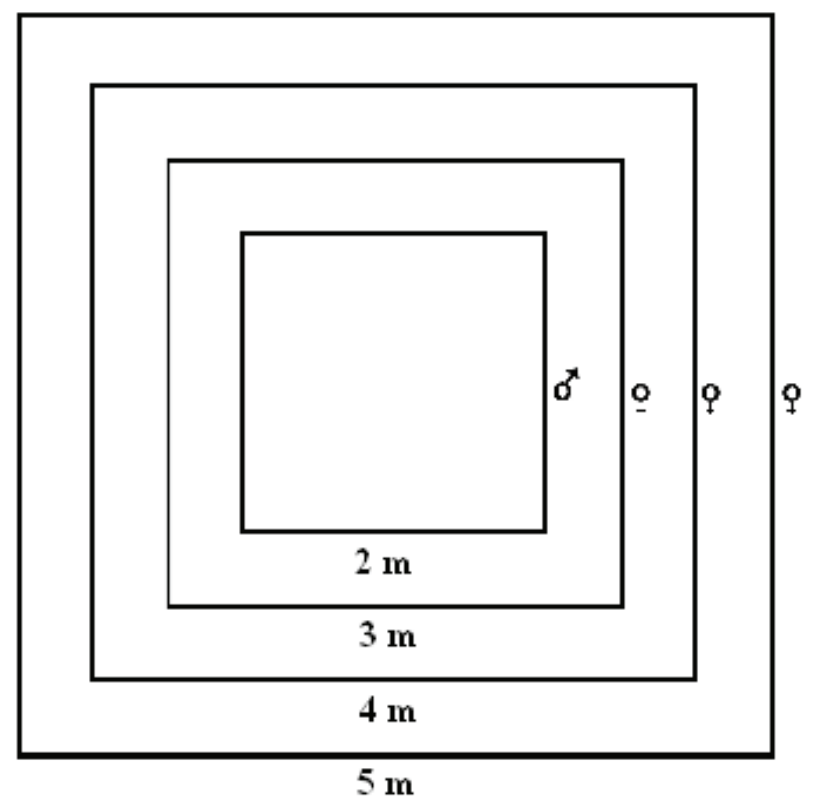

2. E.D.

3. E.D.
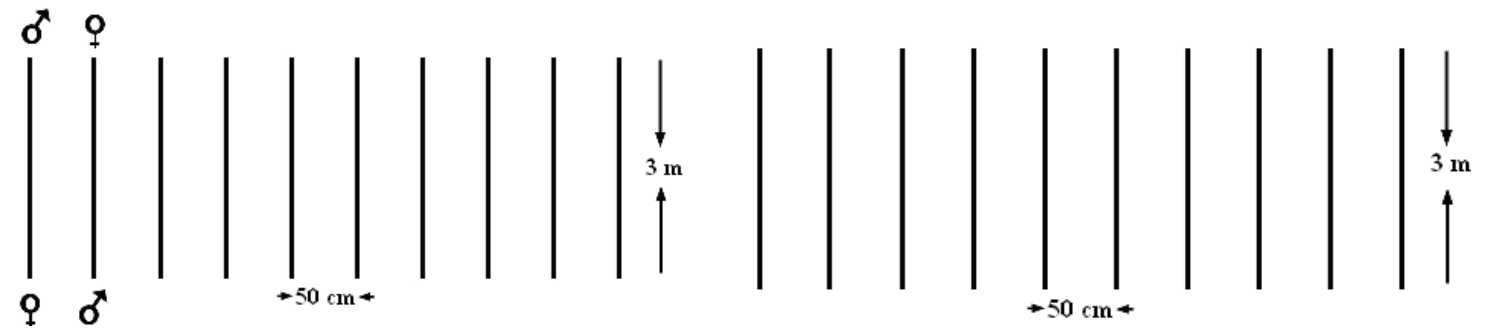

4. E.D.

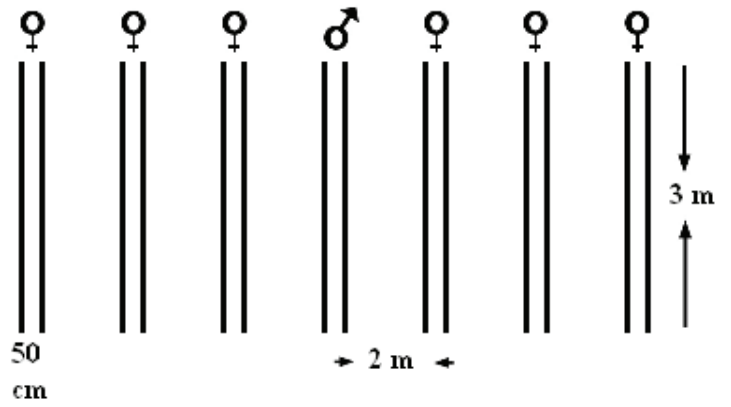

Figure 1- Experimental designs used for determining cross-pollination rate in safflower: E.D., experimental design

Şekil 1- Aspirin yabancı tozlanma oranının belirlenmesinde kullanılan deneme desenleri: E.D., deneme deseni 
donor rows at $200 \mathrm{~cm}, 250 \mathrm{~cm}, 400 \mathrm{~cm}, 450 \mathrm{~cm}, 700$ $\mathrm{cm}$ and $750 \mathrm{~cm}$ spacing.

All plants pollinated under open-pollination conditions. At harvesting (August 2012) only the seeds of pollen receptor plants (spineless and reddish color flowered) were collected in 2012. The seeds collected in 2012 were sown on 27 February 2013 and during harvesting, hybrid plants (spiny and yellow color flowered) were recorded in each row. There was at least $200 \mathrm{~m}$ of isolation distance between four experimental designs.

\section{Results and Discussion}

In the first experimental design, the cross-pollination ratio ranged between $0.48 \%$ and $2.05 \%$ and average value was $1.42 \%$ (Table 1 ). The highest ratio was obtained from innermost square $(50 \mathrm{~cm})$ as $2.05 \%$ while the lowest ratio was in outermost square (150 $\mathrm{cm})$ as $0.48 \%$. In this design, the cross-pollination ratio decreased from the innermost to the outermost square.

In the second experimental design, the crosspollination ratio changed between $2.35 \%-10.64 \%$ and average value was $5.72 \%$ (Table 1). The maximum ratio was recorded in row 2 while the minimum value was row 4 . Cross-pollination ratio showed changes significantly between rows. In the third experimental design, the cross-pollination ratio ranged between $3.57 \%$ and $14.50 \%$ and average value was $7.71 \%$ (Table 1 ). The highest ratio was obtained from row 9 while the lowest ratio was in row 8. Among the experimental design, the maximum average ratio was recorded from third experimental design as $7.71 \%$. This result was affected by the receptor and donor plants to be mixed in the same row.

In the fourth experimental design, the crosspollination ratio ranged between $0.56 \%-2.43 \%$ and average ratio was $1.46 \%$ in south direction while the ratio changed between $0.48 \%-2.47 \%$ and average value was $1.12 \%$ in north direction (Table 1 ). The highest ratio was recorded in the rows, which had a distance of $200 \mathrm{~cm}$ from the donor plants in both directions. The lowest ratio $(0.56 \%)$ was obtained in the row of $750 \mathrm{~cm}$ from donor plants in south direction while it was $0.48 \%$ in the row of $700 \mathrm{~cm}$ from donor plants in north direction. There was no important difference between directions although the prevailing wind in Ankara condition from the north (MSP 1989). Crane \& Walker (1984) have reported that about $80 \%$ of cross-pollination carried out by insects especially honey bees. Similarly, in Ankara conditions mostly honey bees were effective for cross-pollination in safflower. First and fourth experimental designs also showed that crosspollination became higher in the rows which closer to pollen donor plants.

Overall, the general average cross-pollination ratio in safflower was 3.49\% in Ankara conditions. Also some differences were occurred among experimental designs regarding cross-pollination. Gadekar \& Jambhale (2002) indicated that the segregation pattern observed in $\mathrm{F}_{2}$ of both crosses fitted as 3 (donor) : 1 (receptor) ratio. Also Golkar et al (2010) reported the same ratio. The hybridizations in these two studies were done by manually. However real cross-pollination should be occurred in open pollination conditions (Arslan \& Gürbüz 1988). Gürbüz \& Ekiz (1990) reported that the combinations of Oleicleed x 308, Partical-hull $x$ 308, Reduced-hull x 308 and Oleicleed x Reducedhull were left in open pollination and crosspollination ratios were recorded as $16.04 \%, 69.27 \%$, $11.25 \%$ and $21.61 \%$, respectively. According to results of this study, cross-pollination was changed by compatibility between parents.

\section{Conclusions}

The results of the present study can be summarized as follows:

1) Cross-pollination ratios were affected by the experimental designs because of the different positions of donor and receptor plants.

2) The highest cross-pollination ratio was recorded from the third experimental design in which pollen donor and receptor plants were grown in the same row. 
3) There was no clear effect of direction to the cross-pollination probably safflower pollen is not wind-blown.

4) If the distance between donor and receptor plants increases, probability of pollens moving by insects decreases.
5) The compatibility between donor and receptor plants is effective on cross-pollination ratio (Gürbüz \& Ekiz 1990). This situation explained to the lower cross-pollination ratio in the present study more than the previous results.

Table 1- Number of total plants, number of hybrid plants and cross-pollination ratios according to the different experimental designs

Çizelge 1- Farklı deneme desenlerine göre toplam bitki sayıları, melez bitki saylsı ve yabancı tozlanma oranı

\begin{tabular}{|c|c|c|c|c|}
\hline \multicolumn{2}{|c|}{ Experimental designs } & \multirow{2}{*}{$\begin{array}{c}\text { Number of total plants } \\
195\end{array}$} & \multirow{2}{*}{$\frac{\text { Number of hybrid plants }}{4}$} & \multirow{2}{*}{$\begin{array}{c}\text { Cross-pollination ratios (\%) } \\
2.05\end{array}$} \\
\hline \multirow{4}{*}{ 1. E. D. } & 50 & & & \\
\hline & 100 & 174 & 3 & 1.72 \\
\hline & 150 & 210 & 1 & 0.48 \\
\hline & Average & & & 1.42 \\
\hline \multirow{11}{*}{ 2. E. D. } & 1 & 214 & 8 & 3.74 \\
\hline & 2 & 188 & 20 & 10.64 \\
\hline & 3 & 223 & 14 & 6.28 \\
\hline & 4 & 213 & 5 & 2.35 \\
\hline & 5 & 216 & 16 & 7.41 \\
\hline & 6 & 177 & 8 & 4.52 \\
\hline & 7 & 200 & 11 & 5.50 \\
\hline & 8 & 206 & 13 & 6.31 \\
\hline & 9 & 205 & 8 & 3.90 \\
\hline & 10 & 195 & 12 & 6.51 \\
\hline & Average & & & 5.72 \\
\hline \multirow{11}{*}{ 3. E. D. } & 1 & 153 & 13 & 8.50 \\
\hline & 2 & 178 & 8 & 4.49 \\
\hline & 3 & 148 & 20 & 13.51 \\
\hline & 4 & 160 & 10 & 6.25 \\
\hline & 5 & 163 & 12 & 7.36 \\
\hline & 6 & 197 & 11 & 5.58 \\
\hline & 7 & 135 & 13 & 9.63 \\
\hline & 8 & 168 & 6 & 3.57 \\
\hline & 9 & 131 & 19 & 14.50 \\
\hline & 10 & 160 & 6 & 3.75 \\
\hline & Average & & & 7.71 \\
\hline \multirow{15}{*}{ 4. E. D. } & South 200 & 205 & 5 & 2.43 \\
\hline & 250 & 196 & 3 & 1.53 \\
\hline & 450 & 198 & 2 & 1.01 \\
\hline & 500 & 177 & 4 & 2.26 \\
\hline & 700 & 201 & 2 & 0.99 \\
\hline & 750 & 178 & 1 & 0.56 \\
\hline & Average (South) & & & 1.46 \\
\hline & North 200 & 162 & 4 & 2.47 \\
\hline & 250 & 207 & 3 & 1.45 \\
\hline & 450 & 158 & 2 & 1.27 \\
\hline & 500 & 176 & 1 & 0.57 \\
\hline & 700 & 208 & 1 & 0.48 \\
\hline & 750 & 203 & 1 & 0.49 \\
\hline & Average (North) & & & 1.12 \\
\hline & General average & & & 3.49 \\
\hline
\end{tabular}

E.D. ,experimental design 


\section{References}

Arslan N \& Gürbüz B (1988). Bitkilerde yabanc1 döllenme oranını tesbit metotları (Determination of cross-pollination in field crops). Ziraat Mühendisliği Dergisi 208: 23-27

Baydar H \& Gökmen O Y (2003). Hybrid seed production in safflower (Carthamus tinctorius L.) following the induction of mail sterility by gibberellic acid. Plant Breeding 122: 459-461

Classen C E (1950). Natural and controlled crossing in safflower. Agronomy Journal 42: 381-384.

Coşge B \& Kaya D (2008). Performance of some safflower (Carthamus tinctorius L.) varieties sown in late autumn and late spring. Süleyman Demirel Üniversitesi, Fen Bilimleri Enstitüsü Dergisi 12(1): 13-18

Crane E \& Walker P (1984). Pollination Directory for World Crops. International Bee Research Association, London

Gadekar D A \& Jambhale N D (2002). Inheritance of four qualitative characters in safflower (Carthamus tinctorius L.). Sesame and Safflower Newsletter 17:79-80

Golkar P, Arzani A \& Rezaei A M (2010). Inheritance of flower color and spinelessness in safflower (Carthamus tinctorius L.). Journal of Genetics $\mathbf{8 9}(2)$ : 259-262

Gürbüz B \& Ekiz E (1990). Bazı aspir (Carthamus tinctorius L.) çeşitlerinde melez ve yabancı dölenme oranının belirlenmesi. Ankara Üniversitesi, Ziraat Fakültesi Yıllığ 41(1-2):121-127

Knowles P F (1989). Safflower: In oil crops of the World. Mcgraw-Hillpublishers, London, pp: 361-374

MSP (1989). Türkiye Klima Atlası (Climate Atlas of Turkey). Turkish State Meteorological Service Publication, Ankara

Nabloussi A, Velasco L \& Fernandez-Martines J M (2013). Cross pollination of saaflower (Carthamus tinctorius L.) under Moroccan environmental conditions. International Journal of Plant Breeding 7(2): 145-147

Pahlavani M H, Mirlohi AF \& Saeidi G (2004). Inheritance of flower color and spineless in safflower (Carthamus tinctorius L.). Journal of Heredity 95(3): 265-26

Rudolphi S, Becker H C \& Witzke-Ehbrecht S V (2008). Outcrossing rate of safflower (Carthamus tinctorius L.) under the agro climatic conditions of Nothern Germany. Proceedings of the 7th International Safflower Conference, Wagga Wagga, Australia, Noverber 3-6

Velasco L, Fischer M \& Fernandez-Martines J M (2012). Estimation of cross-fertilization rate in safflower (Carthamus tinctorius L.). Spanish Journal of Agricultural Research 10(1): 155-159

Yenice N \& Bayraktar N (1996). Yerli aspir (Carthamus tinctorius L.) hatlarında karyotip analizi. Tarım Bilimleri Dergisi 2(2): 81-86 